\title{
The Empirical Research of Demand Response on the Smart Power Consumers
}

\author{
Yang Bin ${ }^{1, a}$, Ran Wenjun ${ }^{1}$ \\ Shi Kun ${ }^{2, a,{ }^{*}}$ Li Dezhi ${ }^{2}$ \\ ${ }^{1}$ State Grid Jiangsu Electric Power Company, Nanjing, China \\ ${ }^{2}$ China Electric Power Research Institute, Beijing, China \\ a12.East Qinghexiaoying RD.,Haidian Dist.,Beijing,China, shikun@epri.sgcc.com.cn
}

\begin{abstract}
Keywords: demand response, peak shifting and valley filling, load regulation, the electrical behavior with the user
\end{abstract}

Abstract. Demand response in power demand side management plays an important role. In this paper, we achieve the user electrical equipment monitoring through selecting of appropriate scale of residential customers, according to different power consumption behavior pattern, through the deployment of interactive equipment, data acquisition and load control equipment, in response to the incentive mechanism to guide users to participate in power grid peak shifting and valley filling, then this paper Analysis the electricity users behavior change of the load on the grid according to the collected user consumption data changes, in order to explore the incentive mode in response to user demand and verify the effect of the construction of smart electricity project, by comparing the experimental group and the control group, the visualization of air conditioning control results can be found that whether the proportion of users, the length of time, or family air conditioning load reduction rate, air conditioning control group are higher than the group of data visualization, it means that the air conditioning group is better than the visual group, it shows that the implementation of load control has great practical effect and potential for implementation in regulation of peak load shifting under the demand response.

\section{Introduction}

At present, Global issues such as energy, resources and environment have become increasingly prominent, which has brought serious challenges to the human survival and economic and social development, at the same time, China's energy resources distribution and the development of power demand is very uneven, which needs to achieve the optimal allocation of energy resources in a wider range, this is the starting point of China's energy development strategy. Demand response is a very good means. But due to the current user demand side management, lack of means of unpredictable changes, power grid scheduling is difficult to achieve optimization, energy saving, security, and lead to huge generation coal consumption. Peak shaving is an effective way to improve the efficiency of electric energy use, energy saving and emission reduction[1-2].

Under this background, in order to give full play to the important role of smart grid technology in power demand side management, the national Power Grid Corp combined with smart grid construction to carry out the research on the load regulation of the residents' air conditioning load. An empirical study on the use of smart electricity has been started in the construction of intelligent community and project, the empirical part of this paper chooses Beijing, Shanghai, Nanchang and Yinchuan as the pilot project and built a number of power fiber to the home and intelligent power pilot area[3-4]. The intelligent power system realizes the real-time interaction between the user and the power grid, and meets the demand of intelligent power management and service.

For different consumer behavior patterns, the paper select the appropriate size of the residents to achieve the user power equipment monitoring through the deployment of two-way interactive equipment, electricity data acquisition and load control equipment etc, then the paper use demand response incentive mechanism to guide users to participate in power grid peak shaving and valley 
filling[5-6], according to the collected user changes in electricity consumption data, the paper analysis the load on the grid effect of user electricity behavior changes so as to explore the user demand in response to excitation mode, validation of smart power project construction effect. it can be found that by comparing the control effect of the visual group and the air conditioning control group, both with the proportion of users, fit time length, or air-conditioning, household load reduction rate, air conditioning control group data were higher than those of group visualization of data, it means air conditioning group effect is obviously superior to the visual group, It shows that the implementation of load regulation under the demand response has a great practical effect and potential.

\section{Main Contents}

\section{Experimental grouping}

Residents were divided into two experimental groups, and a control group was divided into two groups:

The first group: verify the effect of power consumption behavior and power grid load by the electricity visualization

The second group: verify the influence of air conditioning automatic control on power grid load.

The third group: collecte the use of electricity in the group, the user does not participate in the empirical, using the group data and visualization group for comparison.

User grouping and control strategies in each group are shown in Table 2-1

Table 1 user groups and policy table

\begin{tabular}{l|l|l|l|l}
\hline User group & $\begin{array}{l}\text { Air conditioning switch } \\
\text { control }\end{array}$ & $\begin{array}{l}\text { Air conditioning } \\
\text { temperature control }\end{array}$ & $\begin{array}{l}\text { SMS } \\
\text { alert }\end{array}$ & $\begin{array}{l}\text { Installation of intelligent } \\
\text { electrical equipment }\end{array}$ \\
\hline Control group & $\sqrt{ }$ & $\sqrt{ }$ & $\sqrt{ }$ & $\sqrt{ }$ \\
\hline $\begin{array}{l}\text { Visualization } \\
\text { group }\end{array}$ & - & - & $\sqrt{ }$ & $\sqrt{ }$ \\
\hline $\begin{array}{l}\text { Reference } \\
\text { group }\end{array}$ & $\begin{array}{l}\text { Only the power of the group was collected, and the data and } \\
\text { visualization of the group were compared. }\end{array}$ & - \\
\hline
\end{tabular}

The first group: the use of electricity visualization group

Visualization of power consumption is considered to be one of the means to stabilize the peak power. through the smart socket, intelligent terminal and other equipment, it can automatically measure and collect the data of the users of electricity, the user's electricity consumption, electricity, carbon dioxide and other information can be real-time updated. in the arrival of the peak load, it can notify the user via SMS, online notification, etc, the families of first group can use mobile phones, computers, interactive terminal real-time view of their household electricity situation, it through a good interaction so that users can timely adjust their electricity consumption behavior. the schematic diagram of the power visualization is shown in Figure 2-1:
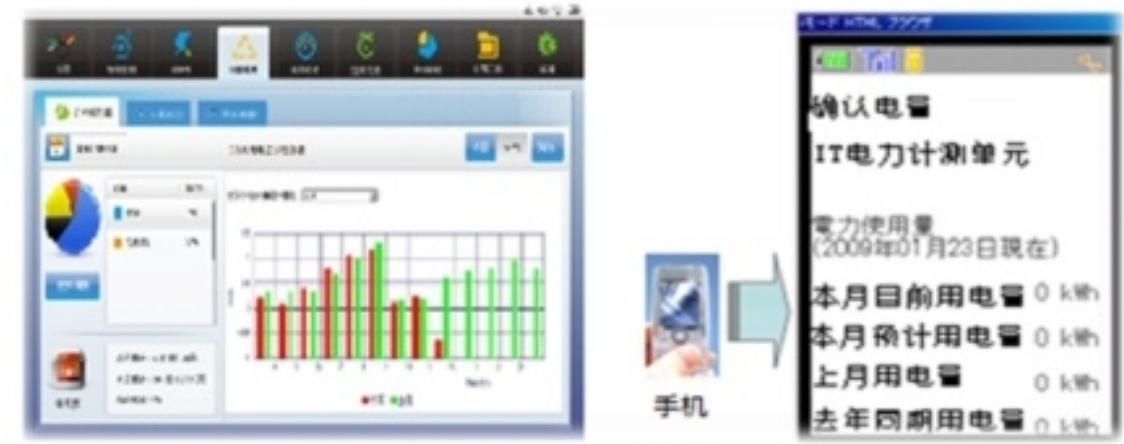

Fig. 1 Schematic diagram of power visualization

The second groups: user visualization + air conditioning control group 
For the families of the second group, the Power Grid Corp will automatically shut down the air conditioning of the second groups of households based on the load situation. but still allow users to manually open after the shutdown. Considering the user may go out when the air conditioning is closed, Power Grid Corp will not automatically open the user's home air conditioning. It will send a message to inform the user to start the air conditioning after the peak load time.

\section{Distribution of user components in pilot cities}

\section{(1) Beijing}

For building one in a residential area in Beijing, according to the outlet of the power distribution cabinet, the Grid collects 50 households in line with the requirements of the electricity visualization + air conditioning automatic control test.

In building two, according to the distribution cabinet outlet situation, the Grid selects 50 users as the third group of benchmark users and makes a establishment of green energy consumption analysis.

(2) Shanghai

In Shanghai, a residential building 2, the Grid Recruited 50 families that meet the requirements, participate in the use of electricity visualization + air conditioning automatic control empirical test. In Shanghai, a residential building 3, the Grid Recruited 50 families that meet the requirements, as third groups of users (baseline users).

(3) Yinchuan

The Grid select the users who are willing to cooperate with the regulation and installation of air conditioning equipment, and had selected more than 50 residents to participate in the use of electricity visualization + air conditioning control test in a district in Yinchuan.

\section{Equipment data acquisition and data preprocessing}

Residents' demonstration project use the user's home installation of smart appliances series products (intelligent interactive terminals, smart home gateway, smart socket, infrared remote control, etc.) to collect the electricity load and power consumption of household electrical appliances, In addition, the project team has transformed and equipped with meter in view of the electric power information collection system to improved the frequency and precision of data acquisition. Acquisition frequency is in Table 2-2. 
Table 2 data acquisition frequency

\begin{tabular}{|c|c|c|c|c|c|}
\hline category & data statistics & $\begin{array}{l}\text { Acquisition } \\
\text { frequency } \\
\text { (minutes / } \\
\text { time) }\end{array}$ & $\begin{array}{l}\text { Shan } \\
\text { g } \\
\text { hai }\end{array}$ & $\begin{array}{l}\text { Bei } \\
\text { jin } \\
\text { g }\end{array}$ & $\begin{array}{l}\text { Yin } \\
\text { chua } \\
\mathrm{n}\end{array}$ \\
\hline \multirow{4}{*}{$\begin{array}{l}\text { Electric meter } \\
\text { data item }\end{array}$} & Residential quarters Variable electric capacity and load & 15 & $\sqrt{ }$ & & $\sqrt{ }$ \\
\hline & Building capacity and load data & 15 & $\sqrt{ }$ & & \\
\hline & Electricity consumption data for household user & 15 & $\sqrt{ }$ & $\sqrt{ }$ & $\sqrt{ }$ \\
\hline & User electric meter load data & 15 & $\sqrt{ }$ & $\sqrt{ }$ & $\sqrt{ }$ \\
\hline \multirow[t]{2}{*}{$\begin{array}{l}\text { Electric meter } \\
\text { history data }\end{array}$} & Residential historic load data & & $\sqrt{ }$ & & $\sqrt{ }$ \\
\hline & The historical data of the residents' electricity meter & & $\sqrt{ }$ & $\sqrt{ }$ & $\sqrt{ }$ \\
\hline \multirow{3}{*}{$\begin{array}{l}\text { Household } \\
\text { electrical } \\
\text { equipment data }\end{array}$} & Air conditioning power & 10 & $\sqrt{ }$ & $\sqrt{ }$ & $\sqrt{ }$ \\
\hline & Power consumption of air conditioner & 60 & $\sqrt{ }$ & $\sqrt{ }$ & $\sqrt{ }$ \\
\hline & $\begin{array}{l}\text { Other electrical appliances (water heater, air } \\
\text { conditioning) power }\end{array}$ & 10 & $\sqrt{ }$ & $\sqrt{ }$ & $\sqrt{ }$ \\
\hline \multirow{2}{*}{$\begin{array}{l}\text { Temperature } \\
\text { data }\end{array}$} & Residential outdoor weather real-time temperature data & 15 & $\sqrt{ }$ & $\sqrt{ }$ & $\sqrt{ }$ \\
\hline & Real time data users building temperature & 15 & $\sqrt{ }$ & $\sqrt{ }$ & $\sqrt{ }$ \\
\hline
\end{tabular}

\section{Residents incentive policy formulation and Implementation}

In order to encourage residents to actively participate in the regulation of electricity load, power grid need to give users a certain basic labor costs to mobilize the enthusiasm of the residents to participate in the smart electricity. In addition to the basic labor costs, the program also refers to the contribution of shifting peak and filling valley, the user air conditioning control and other factors to develop a user incentive program

(1) Basic labor costs: For the first group and second group families participating in the electric experience program for load regulation, In accordance with the use of 200 degrees every month as the basis for the basic payment of labor, users get 100 yuan basic labor every month with 0.5 yuan one kilowatt.

(2) The contribution of shifting peak and filling valley: The contribution of residential electricity to the shifting peak and filling valley will be reflected in the form of analog peak valley electricity price, the first group and the second group of users are calculated by using the simulated peak and valley price charging method and it called 'analog peak and valley electricity bills'

The contribution of shifting peak and filling valley= Original electricity bills-analog peak and valley electricity bills

The benefit of this is: the greater the contribution they make to the peak shift, the more the incentive they will have. So on the basis of the basic service fee, the contribution of the shifting peak and filling valley is supplemented by this kind of incentive method, which is suitable for all users in the experiment.

(3) User air conditioning control: Power grid using centralized air-conditioning control measures for the second groups of users, it automatic control the user's air conditioner during the peak period of electricity consumption, Therefore, this program will be assessed on second groups of users with the air-conditioning control of the active degree, the user can get more rewarding when they do better, Reward embodied in the form of integration. Specific methods are as follows: 
1) Statistical user air conditioning control time during the peak hours. The index is expressed in the form of integral.

2) Integration rule: Statistical user air conditioning control time when the user load is reduced to meet certain threshold conditions, take 15 minutes as the smallest unit, Air conditioning control get 1 points for every 15 minutes, every 1 points $=5$ yuan.

(4) Strategy formulation

The first group of families can use mobile phones, computers, interactive terminal to know real-time situation of their household electricity, users can timely understand and adjust their electricity consumption behavior through a good interaction.

For the second groups of families involved in the experiment, when the power load peak arrival, the Power Grid Corp will shut down the air conditioning based on the load situation of the second groups of households to automatically. But they still allow users to manually open the air conditioning after shutdown it. Considering that the users may go out when the air conditioning is off, Power Grid Corp will not automatically open the user's air conditioning and will send a message to inform the user to start the air conditioning when the peak load time.

In the face of the residents of massive information, project group have data cleaning for all collected data, supplement the missing values in the data, identify and correct the outliers in the data, and perfect the data.

\section{Results}

\section{Beijing experimental results}

Table 3-1 statistics the data of the past five years, Beijing, air conditioning every hundred households, according to the survey of the empirical items of the survey statistics every hundred households have reached 189 units of air conditioning in Beijing. User's air conditioning most installed in the living room and bedroom, in the peak period of power grid operation, the user's living room air conditioning have most frequency and the length of time. Therefore, the project will use the user's living room air conditioning as the main control object.

Table 3 The average amount of empirical user air conditioning in Beijing

\begin{tabular}{l|l|l|l|l|l}
\hline & $\begin{array}{l}200 \\
8\end{array}$ & $\begin{array}{l}200 \\
9\end{array}$ & $\begin{array}{l}201 \\
0\end{array}$ & $\begin{array}{l}201 \\
1\end{array}$ & $\begin{array}{l}201 \\
2\end{array}$ \\
\hline $\begin{array}{l}\text { The average household air-conditioning units (units } \\
/ 100 \text { users) }\end{array}$ & 152 & 163 & 169 & 171 & 189 \\
\hline
\end{tabular}

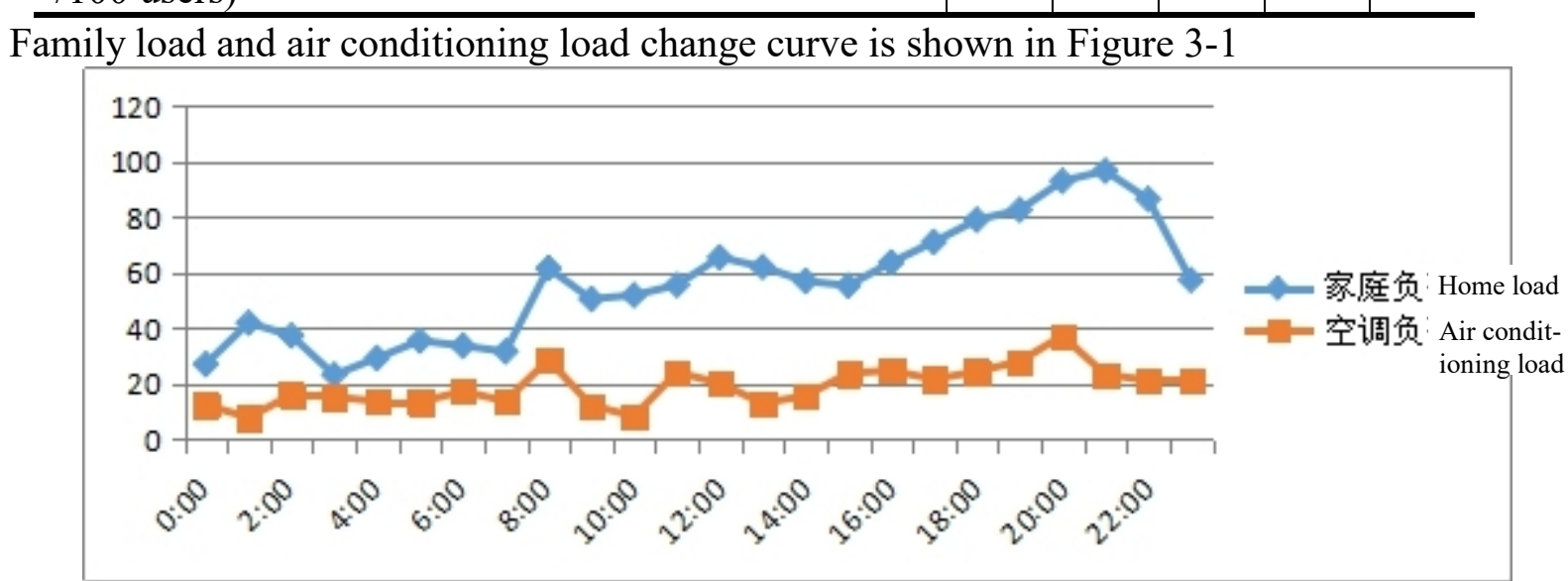

Fig. 2 Family load and air conditioning load change curve

In order to analyze the influence of air conditioning load on the residents' electricity load, the effect of the cooling load of the residents in Beijing in summer was statistically analyzed in Table 3-2. In addition, the project implementation of the process of regulation and control to fully consider the user's comfort experience, only one of the user's home air-conditioning have controlled, the 
implementation of the control of the air conditioning only to detect the load data and other information.

Table 4 Analysis of household electricity load performance (regulation not executed)

\begin{tabular}{l|l|l|l|l|l}
\hline & $\begin{array}{l}\text { The } \\
\text { household } \\
\text { electricity } \\
\text { peak load } \\
(\mathrm{kW})\end{array}$ & $\begin{array}{l}\text { The lowest } \\
\text { household } \\
\text { electricity } \\
\text { load } \\
(\mathrm{kW})\end{array}$ & $\begin{array}{l}\text { The average } \\
\text { household } \\
\text { electricity load } \\
(\mathrm{kW})\end{array}$ & $\begin{array}{l}\text { Air conditioning load } \\
\text { accounted for average } \\
\text { household load (\%) }\end{array}$ & $\begin{array}{l}\text { Peak contribution rate } \\
\text { of air conditioning load } \\
\text { to household load }(\%)\end{array}$ \\
\hline $\begin{array}{l}\text { Visualization } \\
\text { group }\end{array}$ & 99.96 & 26.64 & 48.46 & $24.23 \%$ & $32.38 \%$ \\
\hline Control group & 102.94 & 22.42 & 46.62 & $26.53 \%$ & $30.79 \%$ \\
\hline
\end{tabular}

According to the household electricity load performance evaluation index system of index calculation rules measure visualization group and controlled group of users not to execute the regulation effect, analysis the accounts for the air conditioning load of family average load ratio and air conditioning load contribution to the family load peak of two groups, we can see before implement the control strategy for two groups of users, the gap of the two indicators is small, air conditioning load accounted for the highest peak load reached $32.38 \%$, the average proportion of air conditioning load accounted for $26.53 \%$ of the average household load. Air conditioning is the main factors to push up the peak load to the power grid in summer and continued for a long time, using the rational planning of air conditioning load is a effective measure to stabilize power grid peak.

Visualization group and air conditioning control group were compared and analyzed in the demonstration project in, they were compared by four indicators that are the proportion of users, with the length of time, air conditioning load reduction rate and home load reduction rate, it found that the control group of air conditioning users demand response effect is far better than the visualization group, it shows in Table 3-3.

Table 5 User demand response effect statistics

\begin{tabular}{l|l|l|l|l|l|l}
\hline & \multicolumn{3}{|l}{ Visualization group } & \multicolumn{2}{l}{ Control group } \\
\cline { 2 - 7 } & $\begin{array}{l}\text { Average } \\
\text { value }\end{array}$ & $\begin{array}{l}\text { Maximum } \\
\text { value }\end{array}$ & $\begin{array}{l}\text { Minimum } \\
\text { value }\end{array}$ & $\begin{array}{l}\text { Average } \\
\text { value }\end{array}$ & $\begin{array}{l}\text { Maximum } \\
\text { value }\end{array}$ & $\begin{array}{l}\text { Minimum } \\
\text { value }\end{array}$ \\
\hline $\begin{array}{l}\text { The proportion of } \\
\text { coordination user }\end{array}$ & $9.57 \%$ & $13.86 \%$ & $7.32 \%$ & $93.12 \%$ & $95.44 \%$ & $81.34 \%$ \\
\hline $\begin{array}{l}\text { The length of time } \\
\text { (Minute) }\end{array}$ & 15.23 & 45 & 7 & 27.21 & 60 & 5 \\
\hline $\begin{array}{l}\text { Air conditioning load } \\
\text { reduction rate }\end{array}$ & $6.82 \%$ & $12.43 \%$ & $4.23 \%$ & $43.12 \%$ & $49.54 \%$ & $28.54 \%$ \\
\hline Home load reduction rate & $4.53 \%$ & $6.91 \%$ & $2.12 \%$ & $13.53 \%$ & $19.52 \%$ & $7.32 \%$ \\
\hline
\end{tabular}

It can be seen that the load optimization control can effectively reduce the peak of the power grid, the maximum peak clipping as high as $19.52 \%$. when implement the shutdown operation, The highest proportion of users was $13.86 \%$ in visualization group, it means that the visualization group users have awareness of energy conservation, based on effective peak early warning and controlling visualization method, these user's peak clipping potential can effectively utilize, The highest proportion of users was $95.44 \%$ in control group, In a stable network conditions, load optimal control is the most direct means to cut the peak of power grid, and its average family load reduction rate is $13.53 \%$. it can be used to cut off the air conditioning load in a way to cut power grid peak in power grid crisis.

By comparing the set of visualization group and air conditioning control group members in electricity during the experiment, it can be found that regulation can reduce the peak valley difference 
and improve the household electricity load rate. Air conditioning control group's effect is more pronounced for the reduction of peak and valley poor implementation after the regulation, it turn down to $65.43 \mathrm{KW}$, while household electricity load rate increased from $52.7 \%$ to $60.6 \%$. It can be seen that the implementation of air-conditioning load regulation and control can effectively reduce the peak valley difference. In addition, compared two groups of household electricity load rate level before and after the change, it can be seen that the implementation of the regulation and control of the load from the two groups rates are on the rise, control group load rate increased considerably, thus it can be seen that the implementation of the air conditioning load control can guarantee a more stable operation to the power grid, it is a powerful and fast way to reduce the peak of power grid. Analysis of household electricity load index (regulation contrast) is shown in Table 3-4.

Table 6 Analysis of household electricity load index (regulation contrast)

\begin{tabular}{l|l|l|l}
\hline & Group & $\begin{array}{l}\text { Peak to valley difference } \\
(\mathrm{KW})\end{array}$ & $\begin{array}{l}\text { The household electricity load rate } \\
(\%)\end{array}$ \\
\hline \multirow{3}{*}{ No control } & $\begin{array}{l}\text { Visualization } \\
\text { group }\end{array}$ & 70.31 & $55.2 \%$ \\
\cline { 2 - 4 } & Control group & 74.69 & $52.7 \%$ \\
\hline \multirow{2}{*}{$\begin{array}{l}\text { Execution } \\
\text { control }\end{array}$} & $\begin{array}{l}\text { Visualization } \\
\text { group }\end{array}$ & 68.79 & $59.6 \%$ \\
\cline { 2 - 4 } & Control group & 65.43 & $60.6 \%$ \\
\hline
\end{tabular}

\section{Shanghai experimental results}

Table 3-5 statistics air conditioning every one hundred households share data in the past five years in Shanghai, According to the survey of the empirical project, Shanghai has reached 245 units every 100 households. User's air conditioning most installed in the living room and bedroom, in the peak period of power grid operation, the user's living room air conditioning have most frequency and the length of time. Therefore, the project will use the user's living room air conditioning as the main control object.

Table 7 The average amount of air conditioning users in Shanghai

\begin{tabular}{l|l|l|l|l|l|l}
\hline & $\begin{array}{l}200 \\
8\end{array}$ & $\begin{array}{l}200 \\
9\end{array}$ & $\begin{array}{l}201 \\
0\end{array}$ & $\begin{array}{l}201 \\
1\end{array}$ & $\begin{array}{l}201 \\
2\end{array}$ & $\begin{array}{l}\text { Shangh } \\
\text { ai }\end{array}$ \\
\hline $\begin{array}{l}\text { The average household air-conditioning units (units } \\
/ 100 \text { users) }\end{array}$ & 187 & 196 & 200 & 207 & 213 & 245 \\
\hline
\end{tabular}

Family load and air conditioning load change curve is shown in Figure 3-2

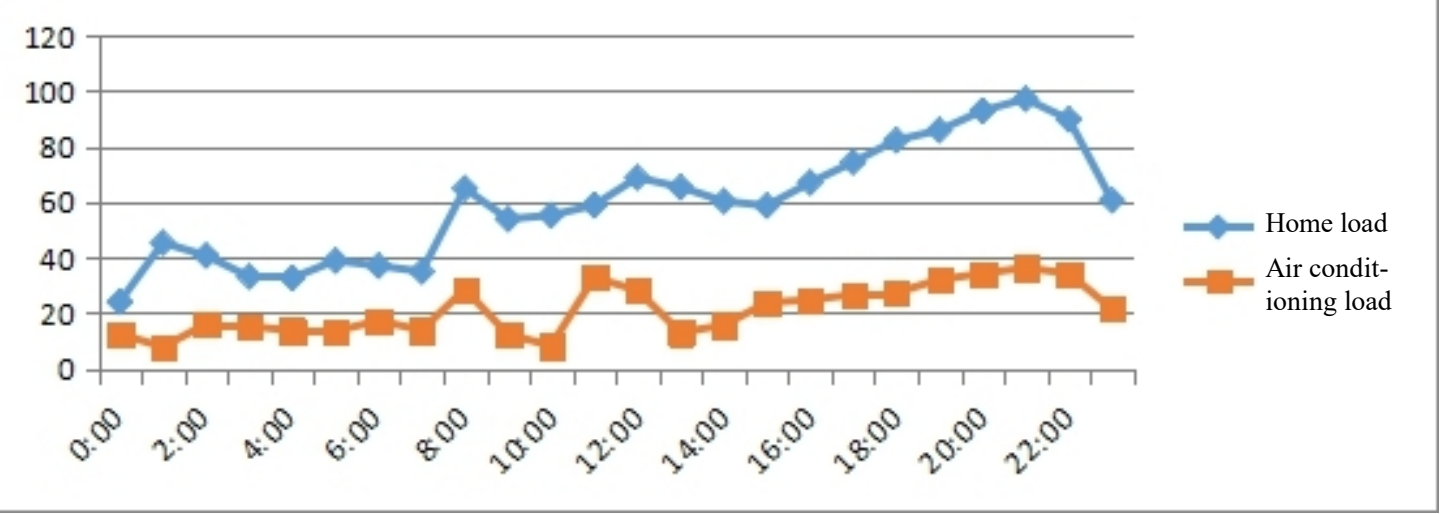

Fig. 3 Family load and air conditioning load change curve

According to the household electricity load performance evaluation index system of index calculation rules measure visualization group and controlled group of users not to execute the regulation effect, analysis the accounts for the air conditioning load of family average load ratio and 
air conditioning load contribution to the family load peak of two groups, we can see before implement the control strategy for two groups of users, the gap of the two indicators is small, air conditioning load accounted for the highest peak load reached $37.10 \%$, the average proportion of air conditioning load accounted for $30.10 \%$ of the average household load. Air conditioning is the main factors to push up the peak load to the power grid in summer and continued for a long time, using the rational planning of air conditioning load is a effective measure to stabilize power grid peak. Analysis of household electricity load performance is shown in Table 3-6.

Table 8 Analysis of household electricity load performance (regulation not executed)

\begin{tabular}{l|l|l|l|l|l}
\hline & $\begin{array}{l}\text { The household } \\
\text { electricity peak } \\
\text { load }(\mathrm{kW})\end{array}$ & $\begin{array}{l}\text { The lowest } \\
\text { household } \\
\text { electricity load } \\
(\mathrm{kW})\end{array}$ & $\begin{array}{l}\text { The average } \\
\text { household } \\
\text { electricity load } \\
(\mathrm{kW})\end{array}$ & $\begin{array}{l}\text { Air conditioning } \\
\text { load accounted for } \\
\text { average household } \\
\text { load }(\%)\end{array}$ & $\begin{array}{l}\text { Peak contribution rate } \\
\text { of air conditioning } \\
\text { load to household } \\
\text { load }(\%)\end{array}$ \\
\hline $\begin{array}{l}\text { Visualizatio } \\
\text { n group }\end{array}$ & 93.74 & 23.43 & 51.76 & $29.30 \%$ & $36.70 \%$ \\
\hline $\begin{array}{l}\text { Control } \\
\text { group }\end{array}$ & 101.14 & 26.45 & 53.31 & $30.10 \%$ & $37.10 \%$ \\
\hline
\end{tabular}

The average maximum temperature in Shanghai is $32^{\circ} \mathrm{C}$, it has controlled 42 days in Shanghai from August to September, Two control strategies of air conditioning and temperature control were performed respectively, Table 3-7 statistics the implementation of the two control strategies during the regulation.

Table 9 User demand response effect statistics in Shanghai

\begin{tabular}{|c|c|c|c|c|c|c|}
\hline \multirow[b]{2}{*}{ Project } & \multicolumn{3}{|c|}{ Visualization group } & \multicolumn{3}{|c|}{ Control group } \\
\hline & $\begin{array}{l}\text { Average } \\
\text { value }\end{array}$ & $\begin{array}{l}\text { Maximu } \\
\text { m value }\end{array}$ & $\begin{array}{l}\text { Minimum } \\
\text { value }\end{array}$ & $\begin{array}{l}\text { Average } \\
\text { value }\end{array}$ & $\begin{array}{l}\text { Maximu } \\
\text { m value }\end{array}$ & $\begin{array}{l}\text { Minimum } \\
\text { value }\end{array}$ \\
\hline \multicolumn{7}{|l|}{ Closure strategy } \\
\hline $\begin{array}{l}\text { The proportion of coordination user } \\
(\%)\end{array}$ & $9.79 \%$ & $13.34 \%$ & $6.23 \%$ & $92.12 \%$ & $96.67 \%$ & $87.56 \%$ \\
\hline Closing time $(\min )$ & 15.14 & 49.56 & 5.78 & 20.74 & 51.24 & 4.37 \\
\hline $\begin{array}{l}\text { Air conditioning load reduction rate } \\
\text { (Group) }(\%)\end{array}$ & $4.80 \%$ & $6.17 \%$ & $3.42 \%$ & $41.79 \%$ & $50.45 \%$ & $33.12 \%$ \\
\hline Home load reduction rate (Group) (\%) & $0.96 \%$ & $1.38 \%$ & $0.53 \%$ & $10.15 \%$ & $12.21 \%$ & $8.08 \%$ \\
\hline \multicolumn{7}{|l|}{ Temperature control strategy } \\
\hline The number of participating $(\%)$ & $13.79 \%$ & $17.34 \%$ & $10.23 \%$ & $92.74 \%$ & $96.91 \%$ & $88.56 \%$ \\
\hline $\begin{array}{l}\text { Temperature regulation and control } \\
\text { time }(\min )\end{array}$ & 20.14 & 53.14 & 13.42 & 23.74 & 52.01 & 20.45 \\
\hline $\begin{array}{l}\text { Air conditioning load reduction rate } \\
\text { (Group) }(\%)\end{array}$ & $1.63 \%$ & $2.04 \%$ & $1.21 \%$ & $16.22 \%$ & $19.32 \%$ & $13.12 \%$ \\
\hline Home load reduction rate (Group) ( \%) & $0.49 \%$ & $0.64 \%$ & $0.33 \%$ & $4.36 \%$ & $5.63 \%$ & $3.08 \%$ \\
\hline
\end{tabular}

Load optimization control can effectively reduce the peak of the power grid, the maximum peak clipping up to $10.15 \%$. When the close operation was performed, the highest proportion of the visualization was $13.34 \%$, which showed that the visualization had the consciousness of saving energy, On the basis of the effective peak control and early warning and visualization tools, the peak clipping potential of this kind of users can be effectively utilized. The users of control group have the maximum user coordination with the degree of $96.67 \%$, In a stable network conditions, Load optimal control is the most direct means to cut the peak of power grid, and its average family load reduction rate is $10.15 \%$. In the power grid crisis it can be used to cut off the power grid peak load. 
Temperature control can be used as the normal peak clipping method, and it has little influence on user's comfort. The implementation of temperature control on the user comfort is less, the average family load reduction rate is $4.36 \%$, this regulation can be used as a means of normal peak clipping. But the temperature control by air conditioning has a greater impact on the performance of the inverter air conditioner and non variable frequency air conditioning load difference is greater, so their has a big difference between the control effect.

The average length of fit time of close means is shorter than that of temperature control, but the load reduction rate is higher. From the above table, it is known that the closing means is shorter than the temperature control means, and the temperature control user has a high degree of acceptance, but the load reduction rate is low. Analysis of household electricity load index is shown in Table 3-8.

Table 10 Analysis of household electricity load index

\begin{tabular}{l|l|l|l}
\hline & Group & Peak to valley difference $(\mathrm{kW})$ & The household electricity load rate $(\%)$ \\
\hline \multirow{2}{*}{ No control } & $\begin{array}{l}\text { Visualization } \\
\text { group }\end{array}$ & 70.31 & $55.2 \%$ \\
\cline { 2 - 4 } & Control group & 74.69 & $52.7 \%$ \\
\hline \multirow{2}{*}{$\begin{array}{l}\text { Execution } \\
\text { control }\end{array}$} & $\begin{array}{l}\text { Visualization } \\
\text { group }\end{array}$ & 68.79 & $59.6 \%$ \\
\cline { 2 - 4 } & Control group & 65.43 & $60.6 \%$ \\
\hline
\end{tabular}

From table 3-8, the peak to valley difference of Visualization group and Control group were 70.31 $\mathrm{kW}$ and $74.69 \mathrm{~kW}$ when they were not controlled, The peak to valley difference were reduced to 68.79 $\mathrm{kW}$ and $65.43 \mathrm{~kW}$ after the implementation of the control strategy, the reductions were $2.2 \%$ and $12.4 \%$, respectively, It can be seen that the implementation of air-conditioning load regulation and control can effectively reduce the peak valley difference. In addition, compared household electricity load rate level of two groups before and after the change, we can know that the load rate of the two groups has increased after the implementation of the regulation, the level of load rate of control group increased more. It can be known that the implementation of air conditioning load control to ensure more stable operation of the power grid, it is a powerful means to reduce the peak power grid and fast way to achieve.

\section{Yinchuan experimental results}

According to the statistical yearbook of Ningxia, every one hundred households have 13.31 air conditionings in Yinchuan in 2011, that means only 1 household have air conditioning of 8 households in Yinchuan, It means that the user is affected by climate and other factor so the demand for the use of air conditioning is small. This project is to study the influence of air conditioning control on the peak load of the residents in Yinchuan, and select the family participation in the pilot area.

By comparing the indicators of user household electricity load performance before the implementation of regulation, the study found that the household electricity load level, household air conditioning load proportion of two groups are similar. Analysis of household electricity load performance (regulation not executed) is shown in Table 3-9.

Table 11 Analysis of household electricity load performance (regulation not executed)

\begin{tabular}{l|l|l|l|l|l}
\hline & $\begin{array}{l}\text { The household } \\
\text { electricity peak } \\
\text { load }(\mathrm{kW})\end{array}$ & $\begin{array}{l}\text { The lowest } \\
\text { household } \\
\text { electricity } \\
\text { load }(\mathrm{kW})\end{array}$ & $\begin{array}{l}\text { The average } \\
\text { household } \\
\text { electricity load } \\
(\mathrm{kW})\end{array}$ & $\begin{array}{l}\text { Air conditioning } \\
\text { load accounted } \\
\text { for average } \\
\text { household load } \\
(\%)\end{array}$ & $\begin{array}{l}\text { Peak contribution } \\
\text { rate of air } \\
\text { conditioning load } \\
\text { to household load } \\
(\%)\end{array}$ \\
\hline Visualization group & 59.74 & 6.88 & 24.76 & $3.87 \%$ & $6.31 \%$ \\
\hline Control group & 60.14 & 6.75 & 24.31 & $4.13 \%$ & $6.62 \%$ \\
\hline
\end{tabular}

Air conditioning load and family load change curve before regulation is shown in Figure 3-3. 


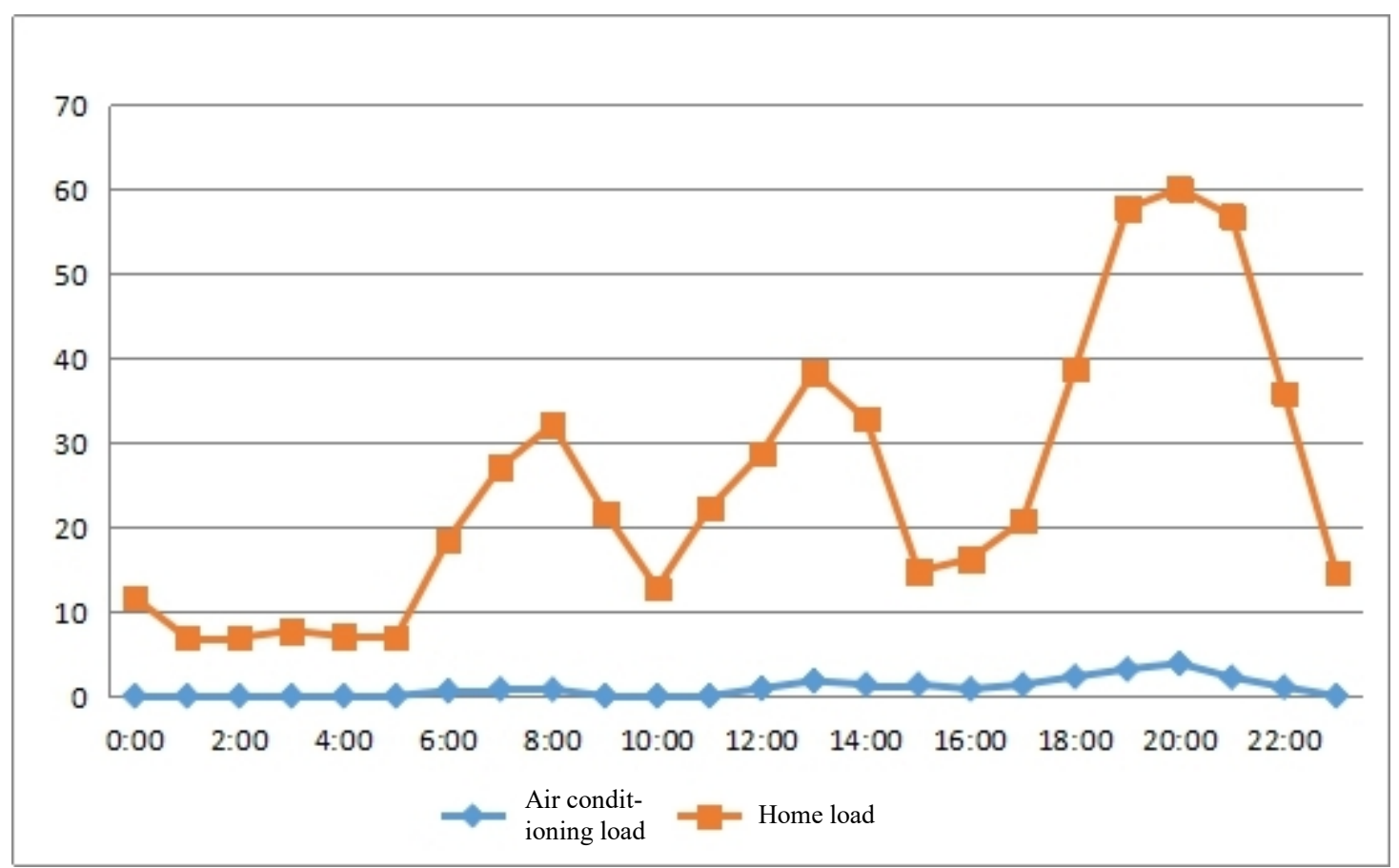

Fig. 4 Air conditioning load and family load change curve before regulation

It can be seen that the air conditioning boot rate is low in Yinchuan, but the use time of air conditioning focused on the 19:00 21:00 that is the peak period of household electricity load, when the household electricity reach to peak load, The proportion of air conditioning load is $6.5 \%$, the average load of the average household load is $4.11 \%$.

Air conditioning load is controlling during household electricity peak hours, Yinchuan pilot user needs response results are shown in table 3-10.

Table 12 Yinchuan pilot user needs response results

\begin{tabular}{l|l|l|l|l|l|l}
\hline & \multicolumn{2}{l}{ Visualization group } & \multicolumn{2}{l}{ Control group } \\
\cline { 2 - 7 } & Average value & $\begin{array}{l}\text { Maximum } \\
\text { value }\end{array}$ & $\begin{array}{l}\text { Minimum } \\
\text { value }\end{array}$ & $\begin{array}{l}\text { Average } \\
\text { value }\end{array}$ & $\begin{array}{l}\text { Maximum } \\
\text { value }\end{array}$ & $\begin{array}{l}\text { Minimum } \\
\text { value }\end{array}$ \\
\hline $\begin{array}{l}\text { The proportion } \\
\text { of coordination } \\
\text { user }\end{array}$ & $68.13 \%$ & $80 \%$ & $25 \%$ & $76.66 \%$ & $100 \%$ & $20 \%$ \\
\hline $\begin{array}{l}\text { Coordination } \\
\text { time (min) }\end{array}$ & 25 & 40 & 20 & 35 & 45 & 25 \\
\hline $\begin{array}{l}\text { Air conditioning } \\
\text { load reduction } \\
\text { rate }\end{array}$ & $66.72 \%$ & $82.18 \%$ & $23.97 \%$ & $79.24 \%$ & $98.25 \%$ & $19.1 \%$ \\
\hline $\begin{array}{l}\text { Home load } \\
\text { reduction rate }\end{array}$ & $1.65 \%$ & $2.42 \%$ & $0.93 \%$ & $2.37 \%$ & $3.39 \%$ & $0.86 \%$ \\
\hline
\end{tabular}

After the air conditioning control commands issued, the overall user have a higher proportion of users, longer coordination time, and air conditioning load reduction rate is higher, but the family load reduction rate is low. The reason is that summer temperatures in Yinchuan are generally not high, the average maximum temperature is $29^{\circ} \mathrm{C}$, residential air conditioning boot rate is low, family load peak air-conditioning load ratio is low, this leads to a lower rate of home load reduction after adjusting the air conditioner.

At the same time, it is not difficult to see that through regulation of the effect of visualization group and an air control group comparison, Whether the proportion of coordination user, coordination time, Air conditioning load reduction rate or home load reduction rate, The data of the air-conditioning 
control group were higher than that of the visible group, that is, the effect of the air-conditioning control group was better than that of the visible group.

Table 3-11 statistics the household electricity load regulation performance index before and after regulation.

Table 13 Analysis of household electricity load index (regulation contrast)

\begin{tabular}{l|l|l|l}
\hline & Group & $\begin{array}{l}\text { Peak to valley difference } \\
(\mathrm{kW})\end{array}$ & $\begin{array}{l}\text { The household electricity } \\
\text { load rate }(\%)\end{array}$ \\
\hline \multirow{2}{*}{ No control } & Visualization group & 52.56 & $41.45 \%$ \\
\cline { 2 - 4 } & Control group & 53.39 & $40.42 \%$ \\
\hline \multirow{2}{*}{ Execution control } & Visualization group & 52.03 & $42.37 \%$ \\
\cline { 2 - 4 } & Control group & 51 & $42.44 \%$ \\
\hline
\end{tabular}

It can be seen from the table 3-11, after regulation, the difference between the two groups was decreased, the peak to valley difference of visualization group decreased by $0.53 \mathrm{~kW}$, and the peak to valley difference of air conditioning control group decreased $2.39 \mathrm{~kW}$, the effect was more obvious. Household electricity load rate also increased after the regulation, especially the air conditioning control group, it is increased from $40.42 \%$ to $42.44 \%$, The group of household electricity load rate has improved.

\section{Conclusions}

This project has selected three representative cities in China to participate in the regulation of air conditioning load as an interrupt load. The results of the project implementation can be seen that the air conditioning load accounted for a large proportion of urban load, the control of the air conditioning load can effectively reduce the peak of the power grid in the residential side, which is an effective way to relieve the peak pressure of power grid and reduce the peak of power grid.

For residents, the air conditioning penetration rate increased year by year, the load control potential is huge, but due to the limited control capacity of single user and large investment costs, it is difficult to effectively coordinate and ensure the implementation effect. But with the improvement of people's living standard, the air conditioning load is increasing year by year, the continuous progress of technology and especially intelligent to promote the construction of electricity will continue to improve user's appliance management level, under the background of the gradual deepening of the increasingly serious problem of energy and energy-saving emission reduction, residential air conditioning negative charge regulation can still be as effective means of emergency cut peak

\section{References}

[1] Zhang W, Lian J, Chang C Y, et al. Aggregated Modeling and Control of Air Conditioning Loads for Demand Response[J]. IEEE Transactions on Power Systems, 2013, 28(4):4655-4664.

[2] Yan C, Xue X, Wang S, et al. A novel air-conditioning system for proactive power demand response to smart grid is [J]. Energy Conversion \& Management, 2014, 102:239-246.

[3] Smith R, Meng K, Dong Z, et al. Demand response: a strategy to address residential air-conditioning peak load in Australia[J]. Journal of Modern Power Systems \& Clean Energy, 2013, $1(3): 223-230$.

[4] Roofegari Nejad R, Moghaddas-Tafreshi S M. A novel method for demand response by air-conditioning systems in a microgrid with considering wind power generation variation[C]// Innovative Smart Grid Technologies - Asia. 2012:1-6. 
[5] Khalid Y I, Hassan N U, Yuen C, et al. Demand response management for power throttling air conditioning loads in residential Smart Grids[C]// IEEE International Conference on Smart Grid Communications. IEEE, 2014:650-655.

[6] Hu X, Wang B, Yang S, et al. A Closed-Loop Control Strategy for Air Conditioning Loads to Participate in Demand Response[J]. Energies, 2015, 8(8):8650-8681. 